University of Michigan Law School

University of Michigan Law School Scholarship Repository

1909

\title{
Combination among Physicians to Fix Prices for Professional Services
}

\author{
Harry B. Hutchins \\ University of Michigan Law School
}

Available at: https://repository.law.umich.edu/articles/1306

Follow this and additional works at: https://repository.law.umich.edu/articles

Part of the Commercial Law Commons, Legislation Commons, and the State and Local Government Law Commons

\section{Recommended Citation}

Hutchins, Harry B. "Combination among Physicians to Fix Prices for Professional Services." Mich. L. Rev. 7 (1909): 237-9.

This Response or Comment is brought to you for free and open access by the Faculty Scholarship at University of Michigan Law School Scholarship Repository. It has been accepted for inclusion in Articles by an authorized administrator of University of Michigan Law School Scholarship Repository. For more information, please contact mlaw.repository@umich.edu. 
Combination among Physicians to Fix Prices for Professional ServICES.- - The case of Rohlf v. Kasemeier et al., decided by the Supreme Court of Iowa, November 18 , I908, and reported in $118 \mathrm{~N}$. W. Rep., p. 276, although primarily upon the construction of a local statute, involves a question of general interest. The plaintiff therein, who is a physician. together with thirteen others of the same profession, all residing and practicing in the same county, entered into an agreement, combination or understanding, the terms of which are not given, but the object of which was to fix and maintain the fees and charges to be exacted for medical and surgical services in said county. The code of the state provided that "any corporation organized under the laws of this or any other state or country for transacting or con- 
ducting any kind of business in this state, or any partnership, association or individual, creating, entering into or becoming a member of, or party to, any pool, trust, agreement, contract, combination, confederation or understanding with any other corporation, partnership, association, or individual to regulate or fix the price of any article of merchandise or commodity, or to fix or limit the amount or quantity of any article, commodity, or merchandise to be manufactured, mined, produced or sold in this state, shall be guilty of conspiracy." The plaintiff and the others who were parties with him in the said agreement, were indicted by a grand jury of the county for entering into a combination to fix and maintain fees contrary to the provisions of the statute hereinbefore quoted. The plaintiff, having been arrested under the indictment, brought habeas corpus proceedings to secure his release from custody, claiming undue and illegal restraint of his liberty, for the reason that no offense known to the laws of the state was charged in the indictment, and for the further reason that "if there be a law forbidding such acts as are charged against him, it is unconstitutional and void, in that it deprives him of his liberty, prevents him from acquiring or possessing property, and deprives him of his safety and the pursuit of his happiness $* * *$ and of the right of contract and of the equal protection of the laws." The trial court discharged the plaintiff and released him from the custody of the sheriff by whom he was held.

It was contended by the appellants in the supreme court that the word "commodity," as used in the statute, is broad enough to cover the charges of a physician or surgeon for his professional services or skill,-indeed, that it is broad enough to cover all kinds of personal labor, both skilled and unskilled. There was perhaps some ground for this contention growing out of a previous holding of the court to the effect that the same word in another statute covered the business of insurance, and that a combination to fix insurance rates would be illegal. See Beechley v. Mivlville, I02 Iowa 602,70 N. W. Rep. IO7, 7I N. W. Rep. 428, 63 Am. St. Rep. 479 . But the court distinguished that case from the one under review by saying in effect that in the former the parties were not selling their own services but were selling insurrance, which might well be regarded as a'"commodity" as that term is used in the statute.

In answering the contention of the appellants, the reviewing court refers first to the rules of construction that should be applied in the case. As the statute is a criminal one, nothing can be added to it by intendment, and ordinarily such an act should have a strict construction. Further, in construing any statute, all the language should be considered, even though we are seeking the construction of but a single word, much of necessity depending upon the context. Moreover, language. in the construction of a statute, should, as a rule, be given its usual and ordinary meaning. Applying these rules, the court finds that the evident intent of the legislature was, not that this statute should cover agreements as to prices for personal labor or effort, whether skilled or unskilled, but rather that it should prevent combinations to regulate or fix the price of movable things, the product of labor and 
industry, or to fix or limit the amount of such things that should be produced. "The statute in question," says the court, "was aimed at unlawful conspiracies or combinations in restraint of trade, and was manifestly not intended to cover labor unions." In regard to the proper interpretation to be put upon the word "commodity," as used in the statute, the court holds that, being a general term, it must, under a settled rule of interpretation, be limited and controlled by the special term "merchandise"; that so limited and controlled it includes movable things that are the products of labor and the subjects of sale, but does not include labor, either skilled or unskilled. To hold that labor is a commodity to be bought, sold or produced like merchandise, would, according to the opinion of the court, be a strained and unnatural construction which ought not to receive judicial sanction. The judgment of the reviewing court that the trial court was right in discharging the plaintiff iertainly has the support of reason and authority. See cases cited.

It may be suggested that the reason for the attempt to bring the agreement of the doctors under this statute is not very apparent. It would seem that it might be for the interest of the public to have the fees of physicians settled and fixed by agreement among themselves, even at high figures, in view of the custom of many in the profession to gauge the charges for services by the ability of the patient to pay.

H. B. H. 